\title{
PENERAPAN EVALUASI DIRI SEKOLAH DASAR MODEL EMI DI KABUPATEN PONOROGO TAHUN 2017
}

\author{
Subangun dan Laily Isroin \\ FKIP Universitas Muhammadiyah Ponorogo \\ Email: pak.b.jozz@gmail.com \\ FIK Universitas Muhammadiyah Ponorogo \\ Email: 1ailyisroin@ymail.com
}

\begin{abstract}
This research is aimed to give an idea about the implementation of selfevaluation of elementary school of Evaluasi Mutu Internal (EMI) model in Kabupaten Ponorogo. This research was conducted in Kabupaten Ponorogo with elementary school research object and elementary school operator in UPTD Kecamatan Jenangan and UPTD Kecamatan Pulung. The approach used in this research is descriptive qualitative. Data collection techniques used are (1) interview, (2) observation, and (3) documentation. The data analysis used is a qualitative technique, namely to examine the problem on a case by case basis because the researcher believes that the nature of a problem one will be different from the nature of the other problem. The results show that self-evaluation of elementary school EMI model becomes alternative for primary school in preparation of self-evaluation. Self-evaluation of elementary school EMI model has advantages because it can be done easily, quickly, efficiently, and effectively. In addition, self-evaluation of the EMI model can be the basis for the preparation of short and long-term school work plans (RKS).
\end{abstract}

\section{Keywords: Self Evaluation, EMI, Character, Superior School}

\begin{abstract}
Abstrak: Penelitian ini secara umum bertujuan untuk memberikan gambaran tentang penerapan evaluasi diri sekolah dasar model Evaluasi Mutu Internal (EMI) di Kabupaten Ponorogo. Penelitian ini dilakukan di Kabupaten Ponorogo dengan objek penelitian kepala sekolah dasar dan operator sekolah dasar di UPTD Kecamatan Jenangan dan UPTD Kecamatan Pulung. Pendekatan yang digunakan dalam penelitian adalah deskriptif kualitatif. Teknik pengumpulan data yang digunakan adalah (1) wawancara, (2) observasi, dan (3) dokumentasi. Adapun analisis data yang digunakan adalah teknik kualitatif, yakni mengkaji masalah secara kasus per kasus karena peneliti yakin bahwa sifat suatu masalah satu akan berbeda dengan sifat dari masalah lainnya. Hasil penelitian menunjukkan bahwa evaluasi diri sekolah dasar model EMI menjadi alternatif bagi sekolah dasar dalam penyusunan evaluasi diri. Evaluasi diri sekolah dasar model EMI memiliki kelebihan karena bisa dilakukan dengan mudah, cepat, efisien, dan efektif. Di samping itu, evaluasi diri model EMI bisa menjadi dasar penyusunan rencana kerja sekolah (RKS) jangka pendek dan jangka panjang.
\end{abstract}

Kata kunci: Evaluasi Diri, EMI, Karakter, Sekolah Unggul

\section{PENDAHULUAN}

Dalam Permendiknas Nomor 13 Tahun 2007 tentang Standar Kepala Sekolah/Madrasah dikemukakan bahwa kepala sekolah harus memenuhi syarat kompetensi kepribadian, manajerial, kewirausahaan, supervisi, dan sosial. Selanjutnya, dalam kompetensi manajerial dikemukakan bahwa kepala sekolah harus mampu menyusun perencanaan sekolah/ madrasah untuk berbagai tingkatan perencanaan.

Sementara itu, dalam Permendiknas Nomor 63 Tahun 2009 tentang Sistem Penjaminan Mutu Pendidikan Pasal 2 ayat (2) dikemukakan tujuan SPMP yakni (a) terbangunnya budaya mutu pendidikan formal, nonformal, dan/atau informal serta (e) terbangunnya sistem informasi mutu 
pendidikan formal dan nonformal berbasis teknologi informasi dan komunikasi. Hal ini berarti bahwa kepala sekolah sebagai seorang manajer harus mampu menyusun perencanaan berbasis teknologi informasi dan komunikasi dalam rangka membangun budaya mutu sekolah.

Untuk membuat perencanaan yang baik, kepala sekolah harus mampu menemukenali potensi yang dimiliki sekolah. Salah satu cara menemukenali potensi sekolah, kepala sekolah melakukan evaluasi diri. Evaluasi diri sekolah yang utama dalam membangun budaya mutu adalah evaluasi terhadap delapan standar nasional pendidikan.

Pada kenyataannya saat ini banyak kepala sekolah dasar, dalam penyusunan perencanaan, tidak mendasarkan pada evaluasi diri secara benar. Pada umumnya kepala sekolah menyusun perencanaan berdasarkan keinginan, bukan kebutuhan. Akibatnya, arah dan tujuannya tidak jelas.

Berdasarkan hasil penelitian yang dilakukan Hendarman (2016), dalam penerapan Evaluasi Diri Sekolah (EDS) masih ditemukan sejumlah kendala menyangkut konsep, instrumen yang digunakan, infrastruktur, sumber daya manusia, dan administrasi. Untuk mengatasi kendala-kendala dalam penerapan EDS perlu ada sinergi, koordinasi, dan komitmen antara pemangku kepentingan di tingkat daerah maupun pusat sesuai dengan wewenang masing-masing.

Sementara itu, prasurvei yang dilakukan Nuchron, Sunarto, dan F.X. Sudarsono (2013) menunjukkan bahwa dalam penyusunan EDS masih banyak hal yang harus diperbaiki dan dibenahi, yakni

(1) Belum terciptanya budaya evaluasi diri, masih ada pimpinan sekolah kurang komit, tidak jujur, dan tidak terbuka dalam mengungkap fakta;
(2) Buku Panduan Evaluasi Diri kurang fleksibel dan sulit dipahami;

(3) Instrumen tidak sesuai dengan kondisi perkembangan yang sangat kompleks;

(4) Analisis data tidak memperhatikan tingkat kepentingan setiap komponen dan item pada indikator;

(5) Panduan analisis hasil evaluasi diri tidak disertakan langkah-langkah usaha untuk melakukan tindakan perbaikan sehingga tidak ada solusi pemecahan tarhadap hasil evaluasi diri.

Evaluasi diri sekolah (EDS) yang dalam bahasa Inggris disebut School Self Evaluation (SSE) adalah proses tanggung jawab sekolah dalam mengevaluasi kemajuan dan mendorong sekolah untuk menetapkan prioritas peningkatan mutu sekolah (BPSDMPK-PMP, 2013: 17). Dalam pengertian ini terdapat tiga hal yang harus diperhatikan, yakni

(1) Tanggung jawab sekolah, artinya bahwa pengisian EDS merupakan tanggung jawab sekolah yang terdiri atas kepala sekolah, guru, tenaga kependidikan, siswa, dan komite sekolah;

(2) Evaluasi kemajuan, artinya hasil EDS harus mampu memotret keberhasilan yang dicapai sekolah pada saat ini;

(3) Peningkatan mutu, artinya bahwa hasil EDS menjadi dasar dalam penetapan prioritas peningkatan mutu tahuntahun berikutnya.

Dalam "Bahan Ajar dan Materi Pelatihan dalam Rangka Penguatan Kemampuan Kepala Sekolah/Madrasah" dijelaskan bahwa evaluasi diri sekolah (EDS) adalah evaluasi internal yang dilaksanakan oleh semua pemangku kepentingan pendidikan (stakeholders) untuk mengetahui secara menyeluruh kinerja sekolah dilihat dari pencapaian SPM dan 8 SNP serta mengetahui kekuatan dan kelemahannya sehingga diperoleh masukan 
dan dasar nyata untuk membuat RPS/RKS dalam upaya untuk menumbuhkan budaya peningkatan mutu yang berkelanjutan (2010: 6).

Dari pengertian tersebut ada beberapa hal yang perlu diperhatikan dalam evaluasi diri sekolah, yakni

(1) Evaluasi internal, artinya bahwa evaluasi disusun berdasarkan fakta yang ada di sekolah dan dilakukan oleh pihak internal sekolah;

(2) Pemangku kepentingan, artinya yang harus melakukan evaluasi diri adalah seluruh pemangku kepentingan, meliputi kepala sekolah, guru, tenaga kependidikan, siswa, dan komite sekolah;

(3) Kinerja sekolah, artinya evaluasi diri ini bermanfaat sebagai alat untuk mengukur kinerja sekolah terhadap capaian pemenuhan standar pelayanan minimal (SPM) dan standar nasional pendidikan (SNP);

(4) SPM dan SNP, artinya dasar evaluasi diri adalah capaian standar untuk memenuhi standar pelayanan minimal dan standar nasional pendidikan;

(5) Kekuatan dan kelemahan, artinya dalam evaluasi diri ditekankan pada seberapa besar kekuatan dan kelemahan sekolah dalam memenuhi SPM dan SNP;

(6) RPS/RKS, artinya bahwa hasil evaluasi diri digunakan sebagai dasar penyusunan rencana program sekolah atau rencana kerja sekolah;

(7) Budaya mutu, artinya EDS dilakukan untuk membentuk budaya mutu.

Sementara itu, Hendarman (2014) mengungkapkan bahwa evaluasi diri dimaksudkan sebagai proses pemetaan sekolah yang dilakukan oleh kepala sekolah secara jujur dan transparan sehingga ditemukan akar permasalahan dalam penjaminan mutu pendidikan yang dirumuskan dalam rekomendasi dan langkah nyata. Dari pengertian tersebut perlu diperhatikan bahwa EDS harus dilakukan secara jujur dan transparan, artinya dalam EDS tidak dibenarkan merekayasa atau memanipulasi data sehingga yang dihasilkan apa adanya. Di samping itu, dalam EDS harus benar-benar dicari akar masalahnya sehingga rencana tindak lanjutnya tepat sasaran.

Selanjutnya, dalam buku pedoman pelatihan "Peningkatan Kompetensi Kepala Sekolah dalam Mengelola Implementasi Kurikulum: Evaluasi Diri Sekolah" dikemukakan bahwa EDS adalah proses evaluasi diri sekolah yang bersifat internal dengan melibatkan pemangku kepentingan untuk mengetahui kinerja sekolah berdasarkan SPM dan SNP serta menjadi dasar penyusunan RKS dan masukan dalam perencanaan investasi pendidikan tingkat kabupaten/kota dan pemangku kepentingan lainnya (2015: 3).

Pemerintah, dalam hal ini Kemendikbud, telah menyosialisasikan dan melaksanakan EDS secara online. Akan tetapi, hasilnya belum maksimal. Beberapa hasil penelitian menunjukkan kendala dan kelemahan EDS secara online tersebut sehingga hasilnya belum memenuhi harapan. Hasil penelitian tersebut antara lain dilakukan (1) Fitri Ning Tyas dan Desi Nurhikmahyanti (2014); (2) Hendarman (2016); (3) Muhammad Mauluddin dan Amy Yayuk Sri Rahayu (2016); (4) Nuchron, Sunarto, dan FX Sudarsono (2016); dan (5) Ni Putu Ayu Rastiti (2016)

Tyas dan Desi (2014) menyimpulkan bahwa faktor penghambat secara internal meliputi kejenuhan akan instrumen, kurangnya pemahaman guru, dan waktu yang singkat; sedangkan secara eksternal meliputi perubahan sistem dan instrumen EDS dan banyaknya item pertanyaan. 
Sementara itu, Hendarman (2016) menyimpulkan bahwa kendala yang dihadapi dalam penyusunan EDS meliputi aspek konsep, instrumen, infrastruktur, sumber daya manusia, dan administrasi. Kendala-kendala tersebut disebabkan oleh sosialisasi belum dilakukan secara benar, komitmen sekolah belum ada, dan kerja sama antarpemangku kepentingan belum ada. Oleh karena itu, disarankan oleh peneliti agar ada kebijakan khusus di tingkat kabupaten sebagai payung hukum dalam penyusunan perencanaan, penganggaran, dan pengawasan. Di samping itu, diperlukan pula adanya mekanisme yang menjamin bahwa pelaksanaan EDS dilakukan secara objektif, transparan, dan jujur, serta pengawasan silang untuk menjamin netralitas dan objektivitas hasil EDS.

Di sisi lain, Mauluddin dan Amy (2016) menyimpulkan bahwa pelaksanaan SPMP di SDN Cilandak Timur 08 Pagi Jakarta Selatan belum sesuai dengan petunjuk. Hal ini disebabkan oleh masih lemahnya kemampuan menggunakan IT, kurangnya anggaran, kurangnya waktu pengisian, lemahnya koordinasi dan kerja sama antarpihak, dan kurang relevannya instrumen EDS.

Adapun prasurvei yang dilakukan Nuchron, Sunarto, dan Sudarsono (2016) menunjukkan bahwa dalam penyusunan EDS masih banyak hal yang harus diperbaiki dan dibenahi, yakni

(1) Belum terciptanya budaya evaluasi diri, masih ada pimpinan sekolah kurang komit, tidak jujur, dan tidak terbuka dalam mengungkap fakta;

(2) Buku Panduan Evaluasi Diri kurang fleksibel dan sulit dipahami;

(3) Instrumen tidak sesuai dengan kondisi perkembangan yang sangat kompleks;
(4) Analisis data tidak memperhatikan tingkat kepentingan setiap komponen dan item pada indikator;

(5) Panduan analisis hasil evaluasi diri tidak disertakan langkah-langkah usaha untuk melakukan tindakan perbaikan sehingga tidak ada solusi pemecahan tarhadap hasil evaluasi diri.

Penelitian Rastiti (2016) menyimpulkan bahwa faktor-faktor penghambat yang mempengaruhi hasil pengisian EDS secara online antara lain kurang tersedianya sarana pendukung yang memadai, kurangnya kemampuan menggunakan komputer, kurangnya pemahaman terhadap EDS dan Standar Nasional Pendidikan (SNP), kurangnya komitmen sekolah melaksanakan EDS, dan kurangnya dukungan pemerintah daerah. Akibatnya, guru lebih termotivasi kepada NUPTK daripada pengisian instrumen EDS online, siswa tidak memiliki kesempatan untuk memahami EDS, dan hasil pengisian instrumen EDS online belum mencerminkan kondisi sekolah yang sebenarnya.

EMI atau Evaluai Mutu Internal adalah model evaluasi mutu internal yang dikembangkan oleh Badan Pengembangan Sumber Daya Manusia Pendidikan dan Penjaminan Mutu Pendidikan Pusat Penjaminan Mutu Pendidikan (BPSDMPPMP) yang telah diterapkan di LPTK. EMI merupakan kegiatan sistemik penjaminan mutu penyelenggaraan pendidikan di perguruan tinggi secara internal (internally driven), untuk mengawasi penyelenggaraan pendidikan oleh perguruan tinggi sendiri secara berkelanjutan (continuous improvement).

EMI merupakan instrumen evaluasi diri yang akan ditinjau secara berkala, disesuaikan dengan kondisi-kondisi internal Perguruan Tinggi, praktik baik yang berlaku di Indonesia, tuntutan nasional, 
serta perkembangan di dunia internasional, dengan membuka peluang pengembangan sesuai dengan alternatif model-model evaluasi yang terus berkembang secara dinamis.

Berdasarkan pengertian di atas EMI sekolah dasar dapat diartikan sebagai kegiatan sistemik secara internal oleh sekolah dalam rangka penjaminan mutu secara berkelanjutan yang akan ditinjau secara berkala, disesuaikan dengan kondisikondisi internal sekolah, praktik baik yang berlaku di Indonesia, tuntutan nasional, serta perkembangan di dunia internasional.

Menurut Singgih (2016), tujuan penyusunan EMI adalah

(1) Membantu lembaga dan pemerintah menetapkan program pengembangan menuju pemenuhan SNP;

(2) Mengembangkan budaya mutu; dan

(3) Menyiapkan bahan evaluasi eksternal baik nasional maupun internasional.

Di samping itu, EMI juga bertujuan untuk

(1) Memastikan kesesuaian dokumen mutu dengan standar yang ditetapkan;

(2) Memastikan kesesuaian kegiatan lembaga dengan prosedur mutu yang telah ditetapkan;

(3) Mengetahui ketercapaian sasaran yang telah ditetapkan oleh lembaga;

(4) Memastikan keefektifan penerapan system;

(5) Memberikan masukan sebagai upaya perbaikan secara berkelanjutan (PENS, 2012)

Prinsip pengisian EMI sebagaimana tercantum dalam "Panduan Pengisian EMI LPTK" meliputi

(1) Self assessment, artinya pengisian EMI dilakukan dari, oleh dan untuk lembaga yang bersangkutan;

(2) Objektif dan jujur, artinya pengisian EMI dilakukan berdasarkan data apa adanya atau bukti faktual berbasis data;

(3) Internal, hasil pengisian EMI tidak dipublikasikan kepada umum, tetapi hanya sebagai acuan dalam pengembangan dan penyusunan kebijakan lembaga;

(4) Kontinyu, artinya pengisian EMI dilakukan secara terus-menerus, setiap tahun untuk mengetahui kinerja atau mutu yang dicapai lembaga;

(5) Antisipatif, artinya pengisian EMI dilakukan sebagai antisipasi persiapan evaluasi eksternal, baik oleh pemerintah (akreditasi) maupun pihak lain yang membutuhkan sewaktuwaktu (Singgih, 2013).

\section{METODE}

Penelitian ini dilakukan dengan pendekatan deskriptif kualitatif. Ruang lingkup penelitian ini adalah sekolah dasar di wilayah Kabupaten Ponorogo. Objek penelitian adalah operator dan kepala sekolah dasar di Kabupaten Ponorogo, khususnya di UPTD Kecamatan Jenangan dan UPTD Kecamatan Pulung. Teknik pengumpulan data yang digunakan adalah (1) wawancara, (2) observasi, dan (3) dokumentasi.

Adapun analisis data yang digunakan adalah teknik kualitatif, yakni mengkaji masalah secara kasus per kasus karena peneliti yakin bahwa sifat suatu masalah satu akan berbeda dengan sifat dari masalah lainnya. Dalam penelitian kualitatif, analisis data dilakukan sebelum, selama, dan setelah penelitian. Analisis data yang dilakukan sebelum memasuki lapangan antara lain dilakukan terhadap data hasil studi pendahuluan, yakni mendata sekolah dasar di UPTD Pendidikan Kecamatan Jenangan dan UPTD Pendidikan Kecamatan Pulung Kabupaten Ponorogo. Selanjutnya, analisis data yang dilakukan selama berada di 
lapangan atau pada saat pengumpulan data antara lain melakukan wawancara untuk menambah data sehingga diperoleh data yang lebih lengkap. Adapun analisis data yang dilakukan setelah di lapangan antara lain melalui reduksi data, penyajian data, dan penarikan simpulan/verifikasi.

\section{PEMBAHASAN}

Penyusunan EMI sekolah dasar dimulai dari kegiatan need assessment SNP sekolah dasar. Kegiatan ini dilakukan untuk memperoleh gambaran secara benar tentang standar nasional pendidikan sekolah dasar. Kegiatan dilakukan peneliti bersama dengan beberapa pakar pendidikan untuk menganalisis dan mengkaji secara komprehensif standar nasional pendidikan sekolah dasar. Hasilnya berupa rekomendasi dari tim pakar untuk menggunakan instrumen akreditasi sekolah dasar yang dikeluarkan BAN-S/M.

Kegiatan kedua adalah perumusan instrumen dan penyusunan indikator SNP SD. Berdasarkan rekomendasi dari Tim Pakar dilakukan perumusan indikator standar nasional pendidikan sekolah dasar dengan mengacu kepada Perangkat Akreditasi SD/MI dan Juknis SD yang dikeluarkan BAN-S/M. Selanjutnya, berdasarkan indikator standar nasional pendidikan sekolah dasar yang telah dirumuskan, tim menyusun instrumen berupa jabaran capaian menjadi tujuh kriteria capaian.

Kegiatan ketiga adalah pengumpulan data, observasi, dan rekapitulasi data. Kegiatan lapangan ini dimulai dengan sosialisasi indikator dan instrumen yang telah tersusun kepada seluruh pengawas SD. Dalam sosialisasi peneliti menyampaikan tujuan dan target yang akan dicapai; menyamakan persepsi terhadap penggunaan Evaluasi Diri SD Model EMI; serta menetapkan sekolah yang dipilih sebagai sampel dalam uji coba penggunaan Evaluasi Diri SD Model EMI. Selanjutnya, dilakukan uji coba dengan mengumpulkan data yang dibutuhkan dalam EDS SD di 15 sekolah dasar sampel. Pihak-pihak yang terlibat dalam uji coba Evaluasi Diri SD Model EMI adalah sebagai berikut:

1. Admin Sekolah Dasar

Tugas admin adalah mengisi program aplikasi Evaluasi Diri SD Model EMI.

2. Kepala Sekolah

Tugas kepala sekolah adalah menyampaikan capaian dan target satu tahun mendatang serta rencana dan program perbaikan terhadap estándar yang masih rendah.

3. Pengawas

Tugas pengawas adalah mendampingi dan memberikan arahan terkait berbagai regulasi pemerintah.

4. Pendamping

Tugas pendamping adalah memfasilitasi penggunaan program aplikasi Evaluasi Diri SD Model EMI serta membantu admin apabila ada kesulitan dalam penggunaan program aplikasi.

5. Peneliti

Tugas peneliti adalah mengarahkan pada target yang akan dicapai dalam kegiatan serta menghimpun hasil uji coba.

Bersamaan pengumpulan data dilakukan observasi lapangan sebagai langkah untuk klarifikasi keabsahan data. Selanjutnya, dari data yang diperoleh dilakukan rekapitulasi hasil pengumpulan data. Rekapitulasi data difokuskan pada ketercapaian masing-masing indikator standar nasional pendidikan sekolah dasar. Setelah data berhasil direkapitulasi akan dilakukan penghitungan jumlah indikator SNP yang telah dan belum terpenuhi.

Berdasarkan pelaksanaan uji coba, dengan waktu relatif cepat dapat diketahui 
1. Capaian status akreditasi sekolah.

2. Capaian per standar sehingga standar mana yang harus diperbaiki.
Adapun hasil capaian akreditasi melalui EMI dapat dilihat pada Tabel 1 dan Tabel 2 berikut ini.

3. Nilai akreditasi yang dicapai

Tabel 1 Capaian Standar dan Status Akreditasi Per Sekolah Dasar di UPTD Pendidikan

\begin{tabular}{llcl}
\hline No. & Nama Sekolah & Capaian Standar & Status Akreditasi \\
\hline 1. & SDN I Kemiri & 77,83 & $\mathrm{~B}$ \\
\hline 2. & SDN I Semanding & 86,93 & $\mathrm{~A}$ \\
\hline 3. & SDN 2 Tanjungsari & 78,55 & $\mathrm{~B}$ \\
\hline 4. & SDN Panjeng & 89,86 & $\mathrm{~A}$ \\
\hline 5. & SDN Sedah & 79,60 & $\mathrm{~B}$ \\
\hline 6. & SDN 2 Mrican & 85,81 & $\mathrm{~B}$ \\
\hline 7. & SDN 2 Pintu & 89,01 & $\mathrm{~A}$ \\
\hline 8. & SDN 3 Mrican & 83,89 & $\mathrm{~B}$ \\
\hline 9. & SDN Jimbe & 85,17 & $\mathrm{~B}$ \\
\hline 10. & SDN Pintu & 89,01 & $\mathrm{~A}$ \\
\hline 11. & SDN I Singosaren & 82,41 & $\mathrm{~B}$ \\
\hline 12. & SDN 2 Ngrupit & 78,41 & $\mathrm{~B}$ \\
\hline 13. & SDN 2 Paringan & 84,64 & $\mathrm{~B}$ \\
\hline 14. & SDN 2 Singosaren & 77,25 & $\mathrm{~B}$ \\
\hline 15. & SDN 3 Paringan & 73,61 & $\mathrm{~B}$ \\
\hline Rerata & 82,52 & $\mathrm{~B}$ \\
\hline
\end{tabular}

Berdasarkan Tabel 1, melalui dasar berstatus akreditasi A dan sisanya EMI bisa diketahui bahwa dari lima belas sekolah dasar sampel di sebelas sekolah dasar berstatus Kecamatan Jenangan, empat sekolah akreditasi B.

Tabel 2 Capaian Standar dan Status Akreditasi Per Sekolah Dasar di UPTD Pendidikan Kecamatan Pulung

\begin{tabular}{llcc}
\hline No. & Nama Sekolah & Capaian Standar & Status Akreditasi \\
\hline 1. & SDN I Bedrug & 88.55 & $\mathrm{~A}$ \\
\hline 2. & SDN I Plunturan & 85.89 & $\mathrm{~A}$ \\
\hline 3. & SDN 1 Pulung & 89.20 & $\mathrm{~A}$ \\
\hline 4. & SDN 1 Sidoharjo & 80.40 & $\mathrm{~B}$ \\
\hline 5. & SDN 1 Singgahan & 89.04 & $\mathrm{~A}$ \\
\hline 6. & SDN 1 Wagirkidul & 87.28 & $\mathrm{~A}$ \\
\hline 7. & SDN 2 Bekiring & 80.64 & $\mathrm{~B}$ \\
\hline 8. & SDN 2 Kesugihan & 82.32 & $\mathrm{~B}$ \\
\hline 9. & SDN 2 Pomahan & 88.48 & $\mathrm{~A}$ \\
\hline 10. & SDN 2 Sidoharjo & 95.16 & $\mathrm{~A}$ \\
\hline 11. & SDN Pulung Merdiko & 92.38 & $\mathrm{~A}$ \\
\hline 12. & SDN Wayang & 91.08 & $\mathrm{~A}$ \\
\hline Rerata & 86.72 & $\mathrm{~A}$ \\
\hline
\end{tabular}


Berdasarkan Tabel 2, bisa Sementar itu, rerata capaian per diketahui bahwa dari dua belas sekolah dasar sampel di Kecamatan Pulung, standar dapat dilihat pada Tabel 3 dan sembilan sekolah dasar berstatus Tabel 4 berikut ini.

akreditasi A dan sisanya tiga sekolah dasar berstatus akreditasi B.

Tabel 3 Capaian Per Standar di UPTD Pendidikan Kecamatan Jenangan Tahun 2017

\begin{tabular}{lll}
\hline No. & \multicolumn{1}{c}{ Standar } & Rerata \\
\hline 1. & Standar Isi & 89.16 \\
\hline 2. & Standar Proses & 87.09 \\
\hline 3. & Standar Kompetensi Lulusan & 79.00 \\
\hline 4. & Standar Pendidik dan Tenaga Kependidikan & 82.76 \\
\hline 5. & Standar Sarana dan Prasarana & 75.70 \\
\hline 6. & Standar Pengelolaan & 82.24 \\
\hline 7. & Standar Pembiayaan & 81.08 \\
\hline 8. & Standar Penilaian & 83.20 \\
\hline & Rata-Rata & $\mathbf{8 2 . 5 2}$ \\
\hline
\end{tabular}

Berdasarkan Tabel 3, melalui EMI bisa diketahui bahwa rerata capaian standar tertinggi di UPTD Jenangan adalah standar isi $(89,16)$, sedangkan rerata capaian terendah adalah standar sarana prasarana $(75,70)$. Berdasarkan capaian per standar tersebut, sebagian besar sekolah dasar sampel di Kecamatan Jenangan memberikan rekomendasi tentang pemeliharaan dan pengadaan sarana dan prasarana yang ditujukan kepada pemerintah, dalam hal ini Bupati dan Kepala Dinas Pendidikan dan Kebudayaan serta pihak lainnya

Tabel 4 Capaian Per Standar di UPTD Pendidikan Kecamatan Pulung Tahun 2017

\begin{tabular}{llc} 
No. & \multicolumn{1}{c}{ Standar } & Rerata \\
\hline 1. & Standar Isi & 87.97 \\
\hline 2. & Standar Prses & 90.59 \\
\hline 3. & Standar Kompetensi Lulusan & 83.02 \\
\hline 4. & Standar Pendidik dan Tenaga Kependidikan & 84.79 \\
\hline 5. & Standar Sarana dan Prasarana & 76.81 \\
\hline 6. & Standar Pengelolaan & 86.31 \\
\hline 7. & Standar Pembiayaan & 91.81 \\
\hline 8. & Standar Penilaian & 92.48 \\
\hline & Rata-Rata & $\mathbf{8 6 . 7 2}$ \\
\hline
\end{tabular}


Berdasarkan Tabel 4, melalui EMI bisa diketahui bahwa rerata capaian standar tertinggi di UPTD Pulung adalah standar penilaian $(92,48)$, sedangkan rerata capaian terendah adalah standar sarana prasarana $(76,81)$. Berdasarkan capaian per standar tersebut, sebagian besar sekolah dasar sampel di Kecamatan Jenangan memberikan rekomendasi tentang pemeliharaan dan pengadaan sarana dan prasarana yang ditujukan kepada pemerintah, dalam hal ini Bupati dan Kepala Dinas Pendidikan dan Kebudayaan serta pihak lainnya.

Berdasarkan hasil uji coba Evaluasi Diri Sekolah Dasar Model EMI, kepala sekolah dan admin sekolah mendapat manfaat yang besar karena mereka dengan mudah menetapkan rencana perbaikan. Rencana perbaikan ini lebih terfokus karena berdasarkan capaian per standar. Dalam program aplikasi Evaluasi Diri Sekolah Dasar Model EMI telah disediakan kolom untuk melakukan rencana perbaikan berdasarkan akar penyebab ketidaktercapaian ataupun akar penunjang keberhasilan. Di samping itu, sekolah dengan mudah membuat rekomendasi berdasarkan rencana perbaikan, baik rekomendasi internal maupun eksternal. Rekomendasi internal adalah rekomendasi yang akan dilakukan sekolah sendiri dalam jangka pendek dan jangka panjang. Adapun rekomendasi eksternal adalah rekomendasi yang akan ditujukan kepada Dinas Pendidikan atau masyarakat dalam jangka pendek dan jangka panjang.

Sementara itu, berdasarkan survei kepuasan terhadap penggunaan program aplikasi Evaluasi Diri Sekolah Dasar Model EMI dapat diketahui bahwa menurut admin dan kepala sekolah sebagai berikut:

1. Kejelasan petunjuk pengisian Evaluasi Diri SD Model EMI: sangat jelas 44\% dan jelas $56 \%$;
2. Kemudahan pengisian Evaluasi Diri SD Model EMI: sangat mudah $42 \%$ dan mudah 58\%;

3. Kecepatan pengisian Evaluasi Diri SD Model EMI: sangat cepat 19\%, cepat $81 \%$;

4. Keakuratan hasil Evaluasi Diri SD Model EMI: sangat akurat $16 \%$, akurat $81 \%$; dan kurang akurat $2 \%$;

5. Kesesuaian isi Evaluasi Diri SD Model EMI dengan SNP SD: sangat sesuai 42\% dan sesuai $58 \%$;

6. Pelibatan personil dalam pengisian EDS Model EMI: sangat sedikit 14\%, sedikit $77 \%$; dan banyak $9 \%$;

7. Kemudahan akses pemerolehan hasil Evaluasi Diri Diri SD Model EMI: sangat mudah $37 \%$, mudah $63 \%$, agak sulit 2\%;

8. Kemanfaatan Evaluasi Diri SD Model EMI bagi sekolah: sangat bermanfaat (81\%) dan bermanfaat $19 \%$;

9. Keramahan pendamping dalam pengisian Evaluasi Diri SD Model EMI: sangat ramah $84 \%$ dan ramah $16 \%$;

10. Kemampuan pendamping dalam membantu pengisian Evaluasi Diri SD Model EMI: sangat mampu (67\%) dan mampu $33 \%$.

\section{SIMPULAN}

Dari hasil uji coba dapat disimpulkan bahwa program aplikasi Evaluasi Diri Sekolah Dasar Model EMI memiliki kelebihan dalam kemudahan, kecepatan, dan ketepatan. Kemudahan artinya semua komponen sekolah bisa melakukan tanpa banyak kesulitan. Kecepatan artinya dalam relatif waktu yang tidak lama EDS bisa diselesaikan. Ketepatan artinya semua aspek standar pendidikan sekolah dasar mampu dievaluasi. 


\section{DAFTAR PUSTAKA}

Badan Pengembangan Sumber Daya Manusia Pendidikan dan Penjaminan Mutu Pendidikan Kementerian Pendidikan dan Kebudayaan. 2015. Evaluasi Diri Sekolah. Jakarta: Pusat Pengembangan Tenaga Kependidikan.

Badan Pengembangan Sumber Daya Manusia Pendidikan dan Kebudayaan dan Penjaminan Mutu Pendidikan Pusat Penjaminan Mutu Pendidikan Kementerian Pendidikan dan Kebudayaan. 2012. Evaluasi Mutu Internal Perguruan Tinggi Indonesia. Jakarta: Pusat Penjaminan Mutu Pendidikan, Kementerian Pendidikan dan Kebudayaan.

Direktorat Jenderal Peningkatan Mutu Pendidik dan Tenaga Kependidikan Departemen Pendidikan Nasional. 2010. "Evaluasi Diri Sekolah (EDS): Apa, Mengapa, dan Bagaimana". Bahan Ajar dan Materi Pelatihan dalam Rangka Penguatan Kemampuan Kepala Sekolah/Madrasah diakses 26 April 2016.

Hendarman. 2014. "Kendala-Kendala Pelaksanaan Evaluasi Diri Sekolah (EDS)" jurnaldikbud.kemdikbud.go.id diakses 25 April 2016.

Mauluddin, Muhammad dan Amy Yayuk Sri Rahayu. 2013. "Analisis Pelaksanaan Sistem Penjaminan Mutu Pendidikan (SPMP) Melalui Evaluasi Diri Sekolah (EDS) di SDN Cilandak Timur 08 Pagi Jakarta Selatan. lib.ui.ac.id diakses 26 April 2016.

Nuchron, Sunarto, dan FX Sudarsono. 2013 "Model Evaluasi Diri Sekolah
Menengah Kejuruan di Daerah Istimewa Yogyakarta". Jurnal Pendidikan Vokasi, Vol 3, Nomor 1, Februari 2013.

Permendiknas Nomor 13 Tahun 2007 tentang Standar Kepala Sekolah/Madrasah.

kepri.kemenag.go.id diakses 26 April 2016.

Permendiknas Nomor 63 Tahun 2009 tentang Sistem Penjaminan Mutu Pendidikan. sipma.ui.ac.id diakses 26 April 2016.

Politeknik Elektronika Negeri Surabaya. 2012. "Prosedur Operasional Baku EMI". http://pjm.pens.ac.id diakses 28 April 2016.

Rastiti, Ni Putu Аyи. 2015 "Praktik Pengisian Instrumen Evaluasi Diri Sekolah Online di SDN 3 Banjarangkan Kabupaten Klungkung”. Tesis Program Magister Program Studi Kajian Budaya Program Pascasarjana Universitas Udayana Denpasar dalam www.pps.unud.ac.id diakses 26 April 2016.

Singgih, Moses Laksono. 2013. "Sosialisasi Evaluasi Mutu Internal" (Materi 05). www.moseslsinggih.org diakses 27 April 2016.

Tyas, Fitri Ning dan Desi Nurhikmahyanti. 2014. "Penerapan Program Evaluasi Diri Sekolah (EDS): Studi Kasus di SMA Negeri 1 Gresik". Jurnal Inspirasi Manajemen Pendidikan, Vol. 3 No. 3, Januari 2014. 